\title{
Protecting against or Contributing to the Problem? Sexual Exploitation and Abuse in UN Peacekeeping*1
}

\section{Zusammenfassung}

Trotz ihres Schutzauftrages begehen Soldaten und Polizisten in Friedenseinsätzen der Vereinten Nationen Verbrechen, insbesondere in Form von sexueller Ausbeutung und sexuellem Missbrauch (sexual exploitation and abuse, SEA). Eine in diesem Beitrag dargestellte und ausgewertete Studie zu diesem Phänomen identifiziert bestimmte Risikofaktoren für Einsätze die für solche SEAs besonders anfällig sind: Eine von sexueller Gewalt geprägte Umgebung, die Anwesenheit verletzlicher Bevölkerungsgruppen wie Binnenflüchtlinge und unkontrollierter Kontakt zwischen Blauhelmen und der Bevölkerung. Außerdem werden im Rahmen der Studie "Schutzfaktoren" identifiziert, die die Anzahl solcher Verbrechen wiederum senken können: Eine missionseigene Einheit zur Aufnahme und Verfolgung von SEA, Sensibilisierungstrainings für die anreisenden Blauhelme und Aufklärungsarbeit unter der Bevölkerung. Der hiesige Beitrag fasst die quantitative Analyse der zugrundeliegenden Studie zusammen und verifiziert sie anhand dreier Fallstudien.

\section{Résumé}

Malgré la mission de protection dont ils sont investis, les soldats et policiers commettent des crimes dans le cadre de missions de protection des Nations-Unies, ces crimes prenant la forme en particulier d'exploitations et d'abus sexuels (EAS). Une étude concernant cet état de fait, présentée et évaluée dans cette contribution, identifie un certain nombre de facteurs de risques rendant les interventions susceptibles d'engendrer de tells EAS: une région déjà touchée par la violence sexuelle, la présence de groupes de populations vulnérables tels que des réfugiés nationaux et des contacts non surveillés entre les Casques Bleus et la population. De plus dans le cadre de l'étude sont identifiés des "facteurs de protection" susceptibles de réduire de tels crimes: une unité propre à la mission, destinée à répertorier et poursuivre les EAS, un entraînement des Casques Bleus à la sensibilisation et un travail d'explication au sein des populations. La contribution présentée propose une synthèse de l'étude en question et en vérifie le contenu au moyen de trois études de cas.

* Dr. Kelly Neudorfer ist Übersetzerin in der Abteilung Web-Redaktion und -Entwicklung der Universität Hohenheim.

1 Sections of this article are taken directly or summarized from Neudorfer, Sexual Exploitation and Abuse in UN Peacekeeping, 2015. 
In the spring of 2016, once again stories of United Nations (UN) peacekeeping troops sexually exploiting and abusing the local population could be seen on the news. This time, the Central African Republic was the focus of attention, with over one hundred alleged victims speaking to $U N$ representatives within only a few weeks. ${ }^{2}$ Unfortunately, the problem is hardly a new one. The first time the issue was brought to the public's attention was in 1993 when accusations were made that $U N$ peacekeepers in Cambodia had been sexually abusing locals. The UN Special Representative to the mission at the time, Yasushi Akashi, responded by saying, "Boys will be boys," a phrase that was to become a verbal symbol of the military culture deemed by many to play a large role in the abuse. ${ }^{3}$ The Dyncorp scandal in the $U N$ operation in Bosnia-Herzegovina in the 1990 s, in which $U S$ private military contractors were shown to be involved in forced prostitution and human trafficking, once again brought the topic to the forefront of the international community's consciousness, but there were few consequences. ${ }^{4}$ In 2002 , Save the Children UK published a report that sexual exploitation and abuse of children was pervasive in several West African countries. ${ }^{5}$ And in 2006, the $U N$ under-secretarygeneral for peacekeeping operations stated that his "operating presumption is that this is either a problem or a potential problem in every single one of our missions." 6

Part of the reason this issue may be considered particularly morally abhorrent is that the peacekeepers are sent for ostensibly altruistic reasons to protect the local population. In contrast to more traditional reasons for war such as the defense of a state's own citizens or the acquisition of territory, peacekeeping is unique in that states send their troops to protect another state's population. The mission mandates, passed by the UN Security Council on the basis of Chapter VI (pacific measures) or VII (permits the use of force to protect international peace and security) of the $U N$ Charter, stress that part of the reason the missions are called into life is because of ongoing "sexual violence against women and children" (e.g. S/RES/2149), "widespread sexual violence" (e.g. $\mathrm{S} / \mathrm{RES} / 1925),{ }^{8}$ or "rape and other forms of sexual abuse" (e.g. S/RES/1996). ${ }^{9}$ When the peacekeepers go into the mission and are then party to precisely this kind of abuse, the gulf between the intentions behind the mission and what actually happens is so great as

2 Lederer, More than 100 girls and women have come forward with new sexual abuse accusations against international peacekeepers in Central African Republic, the UN said Thursday, and 3 girls allege that a French military commander forced them to have sex with a dog, Publication date: 31 March 2016, Last accessed: 14 September 2016. http://www.usnews.com/news/world/ articles/2016-03-31/group-says-98-girls-in-c-african-republic-sexually-abused.

3 Ward/Horwood/McEvoy/Shipman/Rumble, The Shame of War, 2007.

4 Human Rights Watch, Hopes Betrayed: Trafficking of Women and Girls to Post-Conflict Bosnia and Herzegovina for Forced Prostitution, Vol. 14 (2002), No. 9(D). Accessed on 5 May 2016: https://www.hrw.org/report/2002/11/26/hopes-betrayed/trafficking-women-and-girlspost-conflict-bosnia-and-herzegovina.

5 Ndulo, The United Nations Responses to the Sexual Abuse and Exploitation of Women and Girls by Peacekeepers During Peacekeeping Missions, Berkeley Journal of International Law 27 (2009), 127-61; Save the Children UK, Sexual Violence \& Exploitation: The Experience of Refugee Children in Guinea, Liberia and Sierra Leone, 2002.

6 Ward, 79 (Fn. 3).

7 UN Security Council, Resolution 2149 (S/RES/2149), 2014.

8 UN Security Council, Resolution 1925 (S/RES/1925), 2010.

9 UN Security Council, Resolution 1996 (S/RES/1996), 2011. 
to raise the question of whether the peacekeeping operations can continue to be justified at all.

However, because the $U N$ recognizes how grave this problem is, it has taken measures to try to prevent this kind of abuse from taking place. Despite its efforts, scandals involving peacekeepers sexually abusing the local population have continued to pop up in the international media, but what factors could be contributing to this problem? The $U N$ has taken several measures to try to restrict the problem, but have any of them been effective?

To answer these questions, this article will first look at what criminological theories - focused almost exclusively on the municipal or national level - can contribute to understanding the unique situation of $U N$ peacekeeping, where nationals from many different countries are put into a position of power in yet another country. A true 'internationalized space,' as it were. Secondly, the factors identified in the theories will be placed in a statistical model to see which had a significant effect on the number of sexual exploitation and abuse (SEA) incidents reported ${ }^{10}$ in the time period of the study (2006-2011). Here it should be emphasized that this is only an exploratory study, as the data available is very limited and subject to bias. After a discussion of the statistical analysis, an in-depth outlook will be given in light of the UN Security Council Resolution 2272 passed on 11 March 2016.

\section{Risk Factor Prevention Paradigm}

In this under-explored area of research, Farrington's risk factor prevention paradigm can provide a good starting point for identifying risk factors and prevention measures that are worth more investigation. ${ }^{11}$ Although the primary criticism of risk factor research is that there is often a lack of a theoretical basis between risk factors and offending, ${ }^{12}$ this study seeks to mitigate that problem by only using those factors which have plausible causal links and for which there is already robust support in other settings.

Because $U N$ recruiting practices did not change over the time frame examined in this study (2006-2011), it can be assumed that the mix of individuals with particular characteristics identified as high-risk by theories focused on aspects inherent to certain individuals remained relatively constant. For that reason, the focus will be placed on

10 Although there are disadvantages to using the number of reported incidents as the dependent variable (Harris, Pathways of Police Misconduct: Problem Behavior Patterns and Trajectories from Two Cohorts, 2010,24), this has still been chosen over the alternative of the substantiated incidents because of the difficulties in investigating crimes in the $U N$ peacekeeping setting (access to witnesses, varying laws of troop-sending countries, etc.). Regardless of which number is chosen for the dependent variable, underreporting is a serious problem that cannot be adequately addressed here due to space limitations. For more information on underreporting in these settings, see Neudorfer (Fn. 1).

11 Farrington, Explaining and Preventing Crime: The Globalization of Knowledge - the American Society of Criminology 1999 Presidential Address, Criminology 38 (2000), 1-24.

12 Case/Haines, Understanding Youth Offending: Risk Factor Research, Policy and Practice, $2009,68$. 
structural theories whose causal mechanisms can be transferred to the peacekeeping setting. ${ }^{13}$

\section{Neighborhood Theories}

One area of criminological theory that lends itself to this study is that of neighborhood theories, specifically those on subcultures and social disorganization. ${ }^{14}$ Kornhauser determined that delinquent behaviors develop within a group that support that behavior a "subculture of delinquency" 15 - and that the subculture develops when social disorganization is present. Socially disorganized communities were considered to be characterized by areas in which the neighbors had little in common, no sense of solidarity, and had little to do with one another. ${ }^{16}$ The social disorganization prohibits the members of the community from working together to prevent or stop crime in their neighborhood. ${ }^{17}$

Kornhauser's contention was that there are certain characteristics of communities which prevent them from creating ties with one another and then becoming socially organized. She claimed that poverty, racial and ethnic diversity, and frequent moves will result in difficulties in building social networks which are usually used by neighborhoods to achieve common goals such as crime reduction. It would therefore be expected for neighborhoods with the aforementioned characteristics to have a corresponding high level of crime, a conclusion that was supported by Kornhauser ${ }^{18}$ and empirically by Bursik and Webb, ${ }^{19}$ who noticed that crime rates in neighborhoods often remain high even if there is a complete population turnover, indicating that the cause of the crime is not to be found at the individual level but in the neighborhood.

The discovery that crime levels in a neighborhood remain high even when old residents move out and new ones move in was investigated further by Rodney Stark, ${ }^{20}$ who proposed a theory based on five structural aspects of urban neighborhoods with high crime including

13 Here it should be noted that this is not to say that individual difference theories are irrelevant. However, because recruiting practices did not change and the mix of individuals can therefore be assumed to have remained constant, a significant change in the number of sexual exploitation and abuse incidents reported is more likely to be traced back to a change in the structural aspects of the missions.

14 Kornhauser/Rosner, Social Sources of Delinquency, 1978; Paternoster/Bachman, Explaining Criminals and Crime: Essays in Contemporary Criminological Theory, 2001; Vold/Bernard/ Snipes, Theoretical Criminology, 2002, 127.

15 Kornhauser, (Fn. 14), 30.

16 Kubrin/Stucky/Krohn, Researching Theories of Crime and Deviance, 2009, 87.

17 Silver and Miller wrote up an excellent summary of studies on the corollary to social disorganization, informal social control, which has been shown to reduce crime rates in neighborhoods (Silver/Miller, Sources of Informal Social Control in Chicago Neighborhoods, Criminology 42 (2004), 551-83).

18 Kornhauser, (Fn. 14).

19 Bursik/Webb, Community Change and Patterns of Delinquency, American Journal of Sociology 88 (1982), 24-42.

20 Stark, Deviant Places: A Theory of the Ecology of Crime, Criminology 25 (1987), 893-909. 
“density (many people in a small area), poverty (people have little money), mixed land use (residences, industries, and stores are all in the same place), residential mobility (people frequently move into, out of, and around the neighborhood), and dilapidation (the buildings themselves are falling apart)."21

The causal mechanisms suggested in Stark's theories as well as the other neighborhood theories can, in many cases, be transferred to the peacekeeping environment. Feelings of anonymity, the key link between social disorganization and crime brought about when there is a lack of social networking, abound in peacekeeping missions. Troops from around the world are sent on a collective mission and spread out across a foreign country. Often the soldiers have difficulty communicating with each other and the local community because of language barriers, and because the soldiers are typically in the mission for only 3 or 6-month tours, there is little time to build up relationships. Three of the other factors explicitly named by the theories have correlates in the peacekeeping field: a subculture of crime, ${ }^{22}$ high residential mobility, ${ }^{23}$ and mixed land use. ${ }^{24}$ These factors will now be looked at in order to transfer the causal logic to the peacekeeping field and develop appropriate hypotheses, with the "neighborhoods" being the countries in which the peacekeeping missions take place.

\section{Subculture of Crime}

Shaw and McKay claimed that the environment of the person was an important factor in criminality because in a neighborhood which approved of delinquency, people would have a higher tendency to become delinquent. ${ }^{25}$ They tied this into their description of social disorganization and said that the subculture of delinquency was more important. $^{26}$

The main idea behind the subculture theory is that "[p] eople who do not follow the norms are criticized or ridiculed by other people in the subculture, and those who follow them are admired and respected." ${ }^{27}$ Wolfgang and Ferracuti developed a theory of a subculture of violence, in which violence is considered to be positive behavior or the norm. ${ }^{28}$ The members of this subculture tended to react violently to situations because this behavior is valued and commended by other members of the subculture and shrinking away from violence would be ridiculed. In short, those individuals who associate

21 Stark (Fn. 20); Vold/et al, (Fn. 14), 128-9.

22 Kornhauser, (Fn. 14), 30; Vold/et al., (Fn. 14), 127.

23 Kornhauser, (Fn. 14), Stark (Fn. 20).

24 Stark, (Fn. 20).

25 Shaw, Brothers in Crime, 1938; Shaw, The Natural History of a Delinquent Career, 1931; Shaw, The Jackroller, 1930; Vold/et al., (Fn. 14), 123.

26 Kornhauser disputed Shaw and McKay's claim that a subculture of delinquency was more decisive in whether delinquent behavior appeared because there first had to be social organization before a subculture can be created (Kornhauser (Fn. 14)). While that may indeed be true, in a peacekeeping environment the new peacekeepers enter into a specific subculture when they arrive, and thus whether social disorganization is the root cause of the subculture is at the moment irrelevant.

27 Bernard/Snipes/Gerould, Vold's Theoretical Criminology, 2010, 185.

28 Wolfgang/Ferracuti, The Subculture of Violence, 1981. 
with people who engage in and approve of criminal behavior will have a higher probability of becoming criminals themselves.

What has been shown to be significant in this theory is that those who associate with people who commit crimes are more likely to engage in criminal behavior. The focus on the individual learning from the subculture may therefore be individual, but the causal mechanism purporting that an atmosphere in which sexual violence is prevalent leads to sexual violence on the part of the peacekeepers is decidedly structural and should remain significant in this study. If there is a great deal of sexual violence in a mission's environment, either by the host country's army, the locals (usually called "gender-based sexual violence") or other peacekeepers, then individual peacekeepers could learn from this behavior and commit sexual exploitation and abuse (SEA) as well. ${ }^{29}$ The level of sexual violence which exists in a particular mission varies depending on the mission and is relevant to a peacekeeping situation - where many countries experience a very high level of sexual violence due to war. We can therefore expect a high level of sexual violence in the mission environment to be a risk factor for SEAs in the mission, leading to the following hypothesis:

H1: More SEAs will be committed by peacekeepers in areas in which there is a high level of sexual violence.

\section{Residential Mobility}

In areas where there is high residential mobility, there is no opportunity to build lasting social networks to reduce crime. In addition, a resident is never sure who the other residents are and therefore is less likely to notice a burglary, for example. This lowers the risk of getting caught, which in turn increases the level of crime. Peacekeeping missions, especially since the $1990 \mathrm{~s}$, typically take place in countries in which there has been (or still is) a civil war, which often means that there is a large portion of internally displaced persons (IDPs). When fleeing through the country or residing in temporary refugee camps, there is often little time to build up social contacts. Other social networks such as villages or extended families who might otherwise support each other in a time of need are often destroyed by civil wars, meaning that a peacekeeper's offer for food and protection in exchange for sex can often seem like a fair trade to a young girl whose family might otherwise starve, especially if she has not been educated as to her rights. ${ }^{30}$ The vulnerability of refugee populations has been reiterated by many studies, which have listed the general conditions of poverty, lack of opportunities to make money, and dependency on the peacekeepers for supplies as contributing factors

29 The subculture of aggressive "militarized masculinity" found in the armed forces could also certainly be considered a relevant subculture for SEAs (Bernard/et al., (Fn. 27), 297); Kraskal Kappeler, To Serve and Pursue: Exploring Police Sexual Violence against Women, in: Michael J Palmiotto (ed.), 2001, 145-67 (149); Messerschmidt, Capitalism, Patriarchy, and Crime: Toward a Socialist Feminist Criminology, 1986; Whitworth, Sandra, Men, Militarism, and UN Peacekeeping: A Gendered Analysis, 2004.). However, this study focuses on the mission environment and not on the peacekeepers themselves.

30 This factor will be addressed in the section below on Structural Labeling Theories. 
to the amount of sexual crimes in and around refugee camps. ${ }^{31}$ The mobility and thus anonymity of the local population in this case can lead to the following hypotheses.

H2: More SEAs will be committed by peacekeepers in areas with a large portion of IDPS. ${ }^{32}$

\section{Mixed Land Use}

Stark claimed that in neighborhoods in which the residents lived where there were places from which they could easily steal (stores, for example), then it was more likely that they would because they would have more chances to do so. ${ }^{33}$ This would be also be the case because the residents could casually watch for the best time to commit a crime by keeping an eye on a particular store or home without drawing attention to themselves. In essence, this is an opportunity argument. If the opportunities for committing crimes increase, then the number of crimes will increase.

For peacekeepers, the opportunity to commit crimes would increase if they were often in contact with the endangered population, a "mixed land use" of sorts between peacekeepers and locals, and without supervision. ${ }^{34}$ There are numerous situations in which the peacekeepers come into contact with the population, both in the context of their duties and in their recreational time. These contacts can provide the chance for the peacekeepers to mix positively with the locals, promoting cultural exchange and a positive impression of the mission in the country and stimulating the local economy. However, if there is no supervision of this time, this also gives them the opportunity to engage in SEAs. This argument is not intended to say that all peacekeepers will make use of any opportunity to sexually abuse the local population. Instead, it should be viewed from the other perspective: a decrease in opportunities (by measures designed to decrease unsupervised time off base) will prevent those peacekeepers who would otherwise engage in SEAs from doing so. As all hypotheses will be formulated positively, this leads to the following hypothesis:

31 Csaky, No One to Turn To: The Underreporting of Child Sexual Exploitation and Abuse by Aid Workers and Peacekeepers, 2008; Kirby/D'Estrée, Peacekeepers, the Military and Human Trafficking: Protecting Whom?, University of St. Thomas Law Journal 6 (2008), 221-46; Milmo, Cahal, UN Troops Buy Sex from Teenage Refugees in Congo Camp, The Independent, 25 May 2004, Accessed 26 June 2010: http://www.independent.co.uk/news/world/ africa/story.jsp?story=524674; Reddick/Hughes, (Fn. 5), IASC Review of Protection from Sexual Exploitation and Abuse by UN, NGO, IOM and IFRC Personnel: Summary Report of Country Case Studies, 2010; Save the Children UK.

32 Important to note here is that the conditions of being an IDP make the refugees more vulnerable to crime because, according to the neighborhood theories, they do not - yet - have social bonds with those living around them. This should not be confused with placing the blame for the crimes with the refugees, as it is the high level of forced displacement and resulting familial and social disruption found in these regions which is responsible for the disintegration of social ties.

33 Stark, (Fn. 20).

34 The mixed land use theory was discussed in the section on neighborhood theories because this is the theory from which it is derived. More opportunity arguments will be discussed in the next section on rational choice theories, however. 
H3: More SEAs will be committed by peacekeepers in areas in which the peacekeepers mix with the locals with limited supervision.

\section{Deterrence Theories and Rational Choice}

These theories argue that in some situations, for example after a natural disaster when the certainty of punishment is atypically low, the opportunity for committing a crime is also unusually high (in the natural disaster situation, the store or home owners might have died or at least fled the area). In these situations, they argue, many more people will commit criminal acts than in normal situations. They are therefore called opportunity or rational-choice theories. The idea behind them is to decrease the benefits and increase the costs of crime, ${ }^{35}$ for example by increasing the certainty of punishment. In 1998, a review of the literature on deterrence showed that more evidence had been found for substantial deterrent effects, ${ }^{36}$ although this leaves it unclear as to which aspect of deterrence (certainty, severity, or celerity) is the determining factor. In a later study, Nagin and Pogarsky showed that in terms of prediction abilities, the order of importance from best to worst was certainty followed by severity followed by celerity. ${ }^{37}$

In the UN peacekeeping missions, there are a number of ways to increase the costs of the crime, perhaps leading to fewer crimes. In the agreements between the UN and member states sending troops to the mission, the UN waives its rights to punish the soldiers. The greatest punishment the UN can impose is to send a soldier home, creating serious problems when it comes to the pursuit of justice. Even if the crime the soldier committed is considered a crime in his home country (in some cases that is not true, for example forced marriage of minors), it is the responsibility of the home country to try and punish the soldier. And even if the will to try the soldier is present, the difficulty of collecting evidence when the victim and crime scene are thousands of miles away is often so daunting that it is simply ignored, making successful prosecution unlikely. Resolution $2272^{38}$ may have an effect on the extent of prosecution, as will be mentioned in the conclusion, but the fact remains that the troop-sending countries are the ones responsible for any criminal punishment meted out to the perpetrators.

If SEA allegations against a peacekeeper are found to be substantiated, then the peacekeeper is immediately returned home and banned from participating in future

35 Clarke, Situational Crime Prevention: Successful Case Studies, 1997; Vold/et al., (Fn. 14), 205.

36 Nagin, Criminal Deterrence Research at the Outset of the Twenty-First Century, in: Tonry (ed.), 1998, 1-42 (1).

37 Bernard/et al., (Fn. 27), 21.

38 Adopted on 11 March 2016, UN Security Council Resolution 2272 calls for collective action against national contingents involved in "widespread and systematic" sexual exploitation and abuse. As a first measure, if such credible evidence of this kind of abuse is shown then the entire contingent - those involved and those not involved - is to be repatriated. Secondly, and perhaps more dramatically, if a country does not show proof that it has adequately followed up on any allegations of sexual exploitation and abuse brought against its troops, then the UN may bar it from contributing troops to future missions. 
peacekeeping missions. ${ }^{39}$ Therefore, if there were a UN office in the mission which was responsible for investigating allegations and training investigators, one could assume that the chances of allegations being substantiated and the peacekeeper being sent home would increase. ${ }^{40}$ That, then, would have a deterrent effect, as the certainty of punishment would increase. ${ }^{41} \mathrm{We}$ can therefore expect a mission which has an office dedicated to receiving reports of SEAs and investigating these to have fewer SEAs, leading to H4:

H4: More SEAs will be committed by peacekeepers in missions in which there is no office responsible for hearing, recording, and investigating reports of crimes by the peacekeepers from the local population.

\section{Structural Labeling Theories}

Another problem that arises in peacekeeping situations is that a multitude of troops from many different nations come together in one environment and are expected not to commit "crimes." If they do and are caught, they are sent home and (in theory) punished accordingly. What crimes are they not to commit, though? In some countries, for example, men can marry girls who are minors, have sexual intercourse with them, and divorce them at a later point in time if the men so desire. If this is not considered a crime in his home culture, what is to stop a peacekeeper from marrying a young local girl, using her as more or less a sex slave for the duration of his tour of duty (in countries where marriages to minor girls are allowed there is also often no law against spousal rape), and then divorcing her before returning to his home country? This question of which behaviors are considered crimes within the UN system would be the focus of a structurally-oriented labeling theory looking at peacekeeping missions.

39 Murphy, An Assessment of UN Efforts to Address Sexual Misconduct by Peacekeeping Personnel, International Peacekeeping 13 (2006), 531-46 (532).

40 Punishment does not necessarily need to mean a prison sentence after standing trial in the peacekeeper's home country. Peacekeeping missions are seen as an attractive posting, and the process to be selected to participate is highly competitive in many countries (Aning, Unintended Consequences of Peace Operation for Troop-Contributing Countries from West Africa: The Case of Ghana, in: Ramesh/Thakur/Aoi/De Coning (eds.), 2007, 133-55 (140)). For better or worse, many soldiers view peacekeeping as a way to make a profit above and beyond their regular salary (Haas/Kernic, Zur Soziologie von UN-Peacekeeping-Einsätzen, 1998, 51; Aning, (Fn. 40), 140), with the troop receiving a much higher salary than in their home country, and in some cases they can equal the amount of their retirement benefits with only one year service in a peacekeeping mission (Murthy, Unintended Consequences of Peace Operations for Troop-Contributing Countries from South Asia, in: Ramesh/Thakur/Aoi/De Coning, 156-70 (163)). In some countries, this is true to such an extent that participation in peacekeeping missions is equated with a higher standard of living after the soldier has returned (Aning, (Fn. 40), 140). If a peacekeeper is found guilty of sexual exploitation or abuse in a $U N$ peacekeeping mission, he is repatriated and black-listed from future missions. In this case, that in itself could be considered a severe enough punishment to suffice for a deterrent effect.

41 Ideally, this office would assist in evidence-collecting in the case of a soldier being sent home to be tried for a SEA crime committed in the field. This would increase the certainty of punishment in the home country and, according to the deterrence and rational-choice theories, could also decrease the number of crimes committed. 
A key element of mitigating the absolute power of the state in these structural labeling theories is education in order to create a consciousness for alternate social models. ${ }^{42}$ If the citizens are educated about what crimes exist and, even more importantly in national contexts, about paths open to them for attempting to change what is considered a crime (by petition in the legislative process, for example), then the power of the state to determine what is and is not a crime is tempered. In a peacekeeping setting, one central way to prevent some SEAs from happening also consists of education and could include education of the incoming troops and of the local population on what is considered a crime in the context of the $U N$ missions.

For example, the peacekeepers can be educated about what the $U N$ considers a crime while they are in the field so that confusion or ignorance is eliminated in cases in which the laws vary on essential points from country to country. While some countries offer pre-mission training to their troops, this is by no means required and is also not standard practice for most nations (although this also may change in the wake of Resolution 2272). Training sessions for troops can be held upon the troops' arrival in the host country, however, and here it can be assumed that the education on what is allowed and prohibited would contribute to a decrease in crime. From these considerations, we can therefore develop the following hypothesis:

H5: More SEAs will be committed by peacekeepers in missions in which there is no in-mission training session with an SEA component.

In $U N$ peacekeeping missions, information can also be provided to local citizens about their rights with train-the-trainers workshops, public education campaigns, and legal support and advice for the local populations. An example of this would be the genderbased violence awareness program in Rwanda. ${ }^{43}$ The effect of these programs could reduce the amount of crimes the peacekeepers commit by empowering the would-be victims to stand up to them. In addition, the local population can be educated about their rights. If the locals know that it is considered a crime for the peacekeepers to ask for sex in exchange for food or material rations, some may become empowered to resist these illegal demands. ${ }^{44}$ Drawing on the logic of the structural labeling theories and the cor-

42 Albrecht, Kriminologie: Eine Grundlegung Zum Strafrecht, 2010.

43 United Nations Development Program, Gender-Based Violence Awareness Program Opens Eyes in Rwanda, 2011, Accessed 6 August 2011: http://www.beta.undp.org/undp/en/home/ ourwork/womenempowerment/successstories/story22.html.

44 While public education campaigns on the rights in regards to sexual crimes will be the variable measured, it should not be forgotten that these locals are often at the mercy of the peacekeepers for supplies. Simply providing them with the knowledge that it is a crime for the peacekeepers to ask for sex in exchange for rations cannot be expected to be sufficient for them to refuse the peacekeepers' offers. In order to empower them more fully, they must also be provided with the support of the $U N$ system so they can easily report the crimes, feel they are taken seriously, and, most importantly, be given an alternative. For example, at points where rations are given out, the $U N$ could set up a reporting station in the immediate vicinity. If a person is asked by a $U N$ peacekeeper to provide sexual favors for the rations, the person could go directly to the reporting station, report the crime, and be accompanied by a member of the $U N$ to receive rations. This aspect is dealt with in the section above on the need for an investigative office to be present in the mission. 
relating policy imperatives for how to reduce crime, we can therefore formulate the following hypotheses:

H6: More SEAs will be committed by peacekeepers in missions in which the local population is not empowered by campaigns on the topic of SEAs and prevention of SEAs.

\section{Analysis}

These six hypotheses were tested in a statistical analysis and then three case studies in a mixed-methods design in order to determine which factors have a significant effect on SEAs in peacekeeping missions. Here only brief summaries of the results can be provided. ${ }^{45}$

\section{Sexual Violence and SEAs}

This hypothesis found strong to moderate support in all four analyses. In the statistical analysis, a high level of sexual violence in the host country was positively and significantly correlated to the number of SEA allegations ( $\mathrm{p}=0.006)$. In UNDOF, UNMIL, and in particular in $M O N U C / M O N U S C O,{ }^{46}$ a strong case for the plausibility of the effects of a violent sexual subculture on the behavior of the peacekeepers could be made. The causal mechanism proposed by criminology is particularly interesting in this case because it provides a bridge between the attitudes toward sexual violence in the host country of a mission and the behavior of the incoming peacekeepers. Although the role of the peacekeepers' origins could not be evaluated in this study, it seems that regardless of the peacekeepers' home environment and attitudes toward sexual behavior, when placed in these mission environments with a high degree of sexual violence and impunity toward such behavior, the risk of the peacekeepers conforming to such norms increases. ${ }^{47}$

This indicates that the higher the level of sexual violence in the host country, the more the $U N$ needs to focus on SEA prevention measures when planning the mission. That is not to say that PSEA (preventing sexual exploitation and abuse) measures can be ignored if there is no sexual violence in the area, as the level of sexual violence is only one of several risk factors, and even with low levels of sexual violence in the host country basic measures to prevent SEAs are in order. Still, if a mission environment has only a low level of sexual violence in combination with low risk in the other areas, then the measures

45 For a detailed description of the quantitative analysis run on the variables and the case studies, see Neudorfer, (Fn. 1).

46 UNDOF is the United Nations Disengagement Observer Forcelocated in the Golan Heights between Israel and Syria;UNMIL is the United Nations Mission in Liberia;MONUC was the United Nations Organization Mission in the Democratic Republic of the Congo until 2010; and MONUSCO was its successor mission, the United Nations Organization Stabilization Mission in the Democratic Republic of the Congo.

47 For a more detailed empirical analysis, see Neudorfer, (Fn. 1), 88, $101 \mathrm{ff} ., 127$ f., 144 f., and 152. 
to prevent SEAs will likely not need to be as extensive. In contrast, if a mission is starting in a country in which there is a high level of sexual violence (particularly in combination with high risk in the other risk factor areas), then comparatively more money and effort should be invested in SEA prevention measures in order to protect the population from the negative unintended consequences the UN mission could bring with it.

\section{Social Organization and SEAs}

This hypothesis found support of its causal mechanism in each of the four analyses. The statistical analysis showed that it is positively and significantly correlated to the dependent variable $(\mathrm{p}=0.000)$. While direct evidence could be found neither in the case study of MONUC nor in that of UNMIL, reports from other sources repeatedly validated the claims behind the hypothesis, namely that a loss of the IDP's social networks leads to greater vulnerability to SEAs. Another causal mechanism for this hypothesis was identified by the case studies, and that is the poverty and therefore dependency experienced by the IDPs (internally displaced persons). Although linked to the loss of social networks, dependency should be considered a separate causal mechanism because it can be counteracted in a different way than the loss of social networks can. The UNDOF case study supported the hypothesis by showing that in this mission, where no SEAs were reported, the IDPs in the area had had a chance to rebuild their social networks and were therefore not (as) susceptible to the vulnerability, poverty, and dependency seen in other mission environments where SEAs were prevalent. By creating programs which allow for the IDPs to work and thus become less reliant on humanitarian aid, their vulnerability to SEAs due to their dependency could be combated. ${ }^{48}$

It seems clear from the empirical evidence that a higher number of IDPs in a country leads to a higher number of SEAs, likely due to the peacekeepers' access to a particularly vulnerable population. When putting together future missions, this is a factor the $U N$ should keep in mind. By knowing in advance that a mission is at higher risk for increased SEAs, the UN can take steps in the planning phase to ensure that extra measures, such as those identified by the prevention hypotheses, are in place from the outset of the mission.

\section{Contact with Limited Supervision}

While the direction of the effect for H3 is correct, it was not found to be significant in the statistical analysis. However, it must be noted here that the proxy chosen, that is, the type of mandate (traditional or robust), is a very weak one for this hypothesis. Better would be an index made up of factors such as which anti-fraternization policies were implemented at what time (off-limits locations, off-duty uniform requirement, requirement to participate in leisure activities on base, short contact hours with the local population under supervision, and withholding of pay until the peacekeepers return home). However, aggregate data on these factors was simply not available.

48 For a more detailed empirical analysis, see Neudorfer, (Fn. 1), 89 f., 107ff., 129ff., 145, and $152 \mathrm{f}$. 
The UNDOF case study showed that in a mission with an almost complete lack of opportunities due to the peacekeepers' physical separation from the population, no SEAs were reported in the mission. ${ }^{49}$ For the case of $U N M I L$, there was not enough evidence to say whether anti-fraternization policies might have played a role in the decrease in SEAs in UNMIL, but based on other reports, the causal mechanism doesn't seem implausible. Due to a few OIOS (Office of Internal Oversight Services) reports describing some of the specific measures taken by various contingents and the results in terms of the number of SEA allegations each contingent had, however, the case for this hypothesis in the Democratic Republic of the Congo $(D R C)$ is extremely strong. Particularly measures such as withholding peacekeepers' pay until they return home from their tour of duty, ensuring that they can (and in some cases must) be involved in leisure activities on base, and limiting their contact with the local population seemed to have had a significant impact on reducing SEAs. In fact, because the evidence in the $D R C$ so clearly points to these policies playing a major role in a decrease in SEAs, future missions should press for a sufficient budget to provide these opportunities to the troops. ${ }^{50}$

When considering this factor, there might be a temptation to view it as a call to keep the peacekeepers locked up in the barracks to prevent contact with the local population. While that might be an effective way of preventing any SEAs from occurring, it would be counterproductive to the mission for obvious reasons. In addition, the peacekeepers' contact with locals can have positive effects both in terms of hard indicators such as the stimulus to the local economy (although the negative economic effects must then also be brought into the discussion) and in terms of "softer" factors such as constructive cultural experiences for the locals and the peacekeepers. Out of the measures mentioned, however, there are many that do not include barricading the peacekeepers on their bases to keep them away from the population. Measures such as providing free and frequent contact to their families back home, recreational activities on base, more frequent shift rotations to prevent boredom, or requiring the peacekeepers to wear their uniforms even when off duty could all contribute toward reducing opportunities or anonymity and yet would not separate the peacekeepers from the local population.

\section{Office Responsible for Reporting and Investigating SEAs}

The statistical analysis showed that the introduction of a Conduct and Discipline Unit (CDU) had a significant, negative effect on the number of SEAs in the mission $(\mathrm{p}=0.033)$. This was supported by the case study of MONUC/MONUSCO, where improvements in investigative capacities correlated with the decrease in SEAs between 2006 and 2007, although no conclusion could be drawn about the time period around

49 It should not be overlooked, however, that it seemed common for peacekeepers to spend their leave going to well-known sex tourism destinations and sending explicit postcards back to their comrades (Haas/Kernic, (Fn. 38)). The underlying issue of sexual exploitation was therefore not eliminated entirely but only shifted away from the mission environment. This problem is one which would have to be addressed in a different manner outside of mission policies, however.

50 For a more detailed empirical analysis, see Neudorfer, (Fn. 1), 90 f., 109ff., $131 \mathrm{ff}$., 146 f., and $153 \mathrm{f}$. 
the second decrease in SEAs in that mission. In UNMIL, the evidence suggests that the Conduct and Discipline Unit may have had an effect on the number of SEAs, but the data couldn't be linked to the critical time period and can therefore only be considered to be not implausible.

Overall, it is remarkable that precisely in the years in which the biggest drop in SEA allegations could be seen (between 2006 and 2007), the number of substantiated cases increased dramatically. While the numbers cannot be broken down to a mission level, it does provide some circumstantial evidence that a message was being sent to the incoming peacekeepers that if an allegation was brought against them, there was a very high degree of certainty that they would face the consequence of being sent home and barred from future missions, a factor which could play an important role for many contingents from countries in which the soldiers reap great economic benefits from serving in the UN missions. The statistical analysis reveals that in general, the introduction of a CDU did correlate with the reduction of SEAs throughout all peacekeeping missions. In addition, the MONUC/MONUSCO study supported the hypothesis, and while there is not enough evidence to reach a definitive conclusion one way or another, it is at least possible that the CDU in UNMIL played a role in decreasing the number of violent, nonconsensual SEA incidents. The results of the quantitative analysis and the MONUC/ MONUSCO case study provide enough support for this hypothesis to suggest that money invested in improving investigation techniques will more than likely lower the number of SEAs in a mission, placing these programs towards the top of the priority list for SEA prevention measures in any future missions and in those currently in place. ${ }^{51}$

\section{SEA Training}

This hypothesis found strong support in the case study of MONUC/MONUSCO, but neither the statistical analysis nor the UNMIL case study was able to provide as strong a case. The statistical analysis showed the expected negative relationship between training measures including PSEA and the number of SEA allegations, but this correlation was not significant. It is possible that this is in part due to some endogeneity or sample selection bias in the sample despite the attempts to control for such. In other words, particularly in those missions with high numbers of SEAs, training will be seen as necessary and therefore be more comprehensive. With a true endogeneity problem, however, we would see a positive correlation as meaning that more training would result in more SEAs when, in actuality, the missions with more SEAs would "self-select" to be those with more training. The relationship was negative as expected, though, suggesting that while the attempts to control for selection bias appear to have been successful, either the training did not have a significant effect on the number of SEAs or a small selection bias effect remains. The UNMIL case study does not contradict the hypothesis, but the evidence found is not enough to permit a conclusion except to say that it is not implausible.

It is in the MONUC/MONUSCO case that the strongest support for this hypothesis can be found. The training sessions were continually expanded and improved over the

51 For a more detailed empirical analysis, see Neudorfer, (Fn. 1), 91, 112ff., 133 f., and $154 \mathrm{f}$. 
course of the study's timeframe, with complaints on content criticizing the fact that there was too much information provided in the short training period. In addition, the training sessions were improved both before the first decrease in SEA allegations as well as before the second, further corroborating the hypothesis. Training sessions for peacekeeping personnel are not a given when they arrive in the mission. The high rate of turnover, the numerous languages spoken and frequent lack of a common language, and the deployment to various regions can make it necessary to come up with more creative ways of implementing training sessions such as "cascade" training or training-of-trainers methods. When the effort is put into training sessions, they do seem to pay off, and in the future perhaps continual improvement will more significantly reduce the number of SEAs committed by troops in the missions. ${ }^{52}$

\section{Education and Empowerment}

The final hypothesis was supported by both the statistical analysis $(\mathrm{p}=0.023)$ and the UNMIL case study. The case study of MONUC/MONUSCO unfortunately lacked enough evidence to reach a conclusion, meaning that while the hypothesis is not implausible for this case, there was also no direct evidence that empowerment campaigns played a role in the decrease in SEA allegations.

The statistical analysis, though, showed that the posting of gender advisors in a mission, the position responsible for educating the local population on their rights and empowering them to report SEAs, had a significant, negative effect on the number of SEA allegations the mission experienced. The UNMIL case study revealed that an extensive empowerment campaign was carried out just before the decrease in SEA allegations was recorded, suggesting that this campaign likely played a considerable role in reducing the number of SEAs. As no comparable campaign was carried out by MONUC/MONUS$C O$, it cannot be said whether the effects would have been similar. Because the results were so impressive in UNMIL, however, it would be worth the effort to run another such campaign in a different mission which also has high numbers of SEAs in order to see whether the results were limited to the Liberian case or whether empowerment campaigns would have such an effect on SEAs in other missions, as well..$^{53}$

\section{Conclusion and Outlook}

Thus far, criminology literature has focused primarily on the municipal and national levels, which makes sense both in terms of data availability and from a practical, policyrecommendation perspective since crime-fighting policies are typically developed at these levels. $U N$ peacekeeping represents a unique situation in terms of crime, however, due to the confluence of so many nationalities, the often weak structure of the host country's judiciary, the differing legal situations of the peacekeepers' home countries, and the inability of the $U N$ to try or even discipline the peacekeepers placed under its command by its member states. This study used the risk factor prevention paradigm to

52 For a more detailed empirical analysis, see Neudorfer, (Fn. 1), 92, 117ff., 134ff., and $155 \mathrm{f}$.

53 For a more detailed empirical analysis, see Neudorfer, (Fn. 1), 92, 120ff., 136ff., and 156. 
provide a structure for looking at misconduct in the peacekeeping missions in a pragmatic, solution-oriented manner, following the integrated methods of criminology to identify risk and prevention factors which can contribute to a decrease or increase in crime at a national level and transferring these to the peacekeeping situation. This opens up a new branch for international criminological research aimed not at comparing legal systems or national crime statistics but instead looking at the specific, complex, internationalized space of peacekeeping to try to find ways to explain, prevent, and prosecute misconduct and crimes in this area. Future research can take this further by expanding on individual criminological theories or even developing theories inductively that are specific to the peacekeeping setting.

In summary, it is possible to reduce the amount of sexual exploitation and abuse in $U N$ peacekeeping missions. The numbers show that, indeed, this has already been done to some extent. There is still much work to be done, however, as there is room to improve even the official statistics, and these do not include the large numbers of unreported SEAs. By identifying the at-risk regions, ensuring that all possible measures to prevent SEAs are implemented there, and by implementing those measures which have been shown to be most effective at preventing SEAs in all missions, the $U N$ could make even more progress in the fight against sexual exploitation and abuse.

One big step made recently was the UN Security Council Resolution 2272, passed on 11 March 2016. In this resolution, for the first time in its history the Security Council introduced sanctions for troop-contributing countries to UN peacekeeping missions. If "credible evidence" of "widespread and systematic" sexual exploitation and abuse is found in a particular unit, then the entire unit is to be repatriated. In a second sanction mechanism, if a country cannot provide proof that it has adequately investigated the allegations and, if indicated, criminally prosecuted the perpetrator, then the UN can choose to repatriate the country's entire contingent from that mission and stop accepting troops from that country in future peacekeeping operations. ${ }^{54}$ If implemented fully, this resolution has the potential for far-reaching positive effects. Even if the resolution is not implemented to the fullest extent, however, the signal set by the Security Council is very positive for the fight against sexual exploitation and abuse in $U N$ peacekeeping.

54 For more details on the potential problems with these sanction mechanisms, cf. Neudorfer, (2016). "UNSC Resolution 2272: Progress against Sexual Abuse in UN Peacekeeping?" eInternational Relations. 21 April 2016. http://www.e-ir.info/2016/04/21/unsc-resolution-2272-progress-against-sexual-abuse-in-un-peacekeeping/. 